\title{
Geological Occurrence of Gas Hydrates at the Blake Outer Ridge, Western North Atlantic
}

\author{
Research Report
}

\author{
By \\ K.L. Dominic \\ D.L. Barlow
}

\author{
U.S. Department of Energy \\ Office of Fossil Energy \\ Morgantown Energy Technology Center \\ P.O. Box 880 \\ Morgantown, West Virginia 26507-0880
}

March 1986 



\section{DISCLAIMER}

This report was prepared as an account of work sponsored by an agency of the United States Government. Neither the United States Government nor any agency Thereof, nor any of their employees, makes any warranty, express or implied, or assumes any legal liability or responsibility for the accuracy, completeness, or usefulness of any information, apparatus, product, or process disclosed, or represents that its use would not infringe privately owned rights. Reference herein to any specific commercial product, process, or service by trade name, trademark, manufacturer, or otherwise does not necessarily constitute or imply its endorsement, recommendation, or favoring by the United States Government or any agency thereof. The views and opinions of authors expressed herein do not necessarily state or reflect those of the United States Government or any agency thereof. 


\section{DISCLAIMER}

Portions of this document may be illegible in electronic image products. Images are produced from the best available original document. 


\begin{abstract}
The occurrence of gas hydrates at the Blake Outer Ridge, as confirmed by the Deep Sea Drilling Project (DSDP), is governed not only by gas-water phase relationships but also by interrelated geological constraints. The results of this reexamination of the DSDP data show that seafloor processes, topography, and sediment properties are among the factors that impact the stability and distribution of gas hydrate at the ridge. Rapid sedimentation and erosion have local and transient effects on thermal gradients, which cause the base of the hydrate stability zone to migrate. To a large degree, the convex shape of the Blake Outer Ridge allows gas hydrates to be stable. Low-permeability sediments occupy the interval in which the stability zone exists, and they influence hydrate occurrence by controlling the distribution of gas.

A brief comparison of the Blake Outer Ridge with two more recently confirmed hydrate localities (the northern Gulf of Mexico and the Middle America's trench) shows little similarity among the three hydrate environments, but calls attention to the complex and often subtle effects that the geological system imposes on hydrate stability.
\end{abstract}




\section{ACKNOWLEDGMENTS}

We owe our most sincere thanks to D. Francis, whose ideas and enthusiasm led to the writing of this paper. Thanks to Bob Jacobi and Keith Kvenvolden for their many helpful comments. 
1.0 INTRODUCTION $\ldots \ldots \ldots \ldots \ldots \ldots \ldots \ldots \ldots \ldots \ldots \ldots \ldots \ldots \ldots \ldots \ldots \ldots$

2.0 GEOLOGIC FACTORS CONTROLLING GAS HYDRATE FORMATION $\ldots \ldots \ldots \ldots \ldots \ldots \ldots$

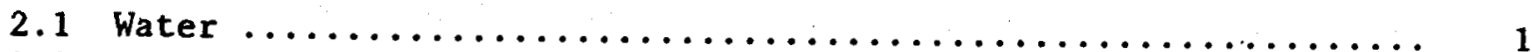

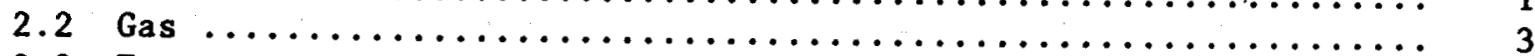

2.3 Temperature and Pressure Conditions $\ldots \ldots \ldots \ldots \ldots \ldots \ldots \ldots \ldots$

3.0 GAS HYDRATE OCCURRENCE AT THE BLAKE OUTER RIDGE $\ldots \ldots \ldots \ldots \ldots \ldots \ldots \ldots .5$

3.1 Geologic Setting ............................. 5

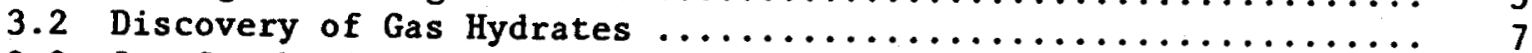

3.3 Gas Geochemistry of Hydrates at Site $533 \ldots \ldots \ldots \ldots \ldots \ldots \ldots \ldots$

4.0 CONTROLS ON HYDRATE OCCURRENCE AT THE BLAKE OUTER RIDGE ........ 10

5.0 OTHER GAS HYDRATE OCCURRENCES $\ldots \ldots \ldots \ldots \ldots \ldots \ldots \ldots \ldots \ldots \ldots \ldots$

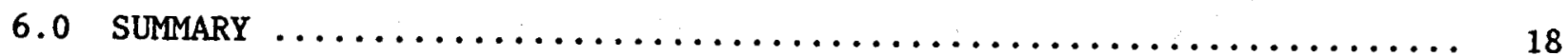

7.0 REFERENCES $\ldots \ldots \ldots \ldots \ldots \ldots \ldots \ldots \ldots \ldots \ldots \ldots \ldots \ldots \ldots \ldots \ldots \ldots \ldots \ldots$ 


\section{LIST OF FIGURES}

Eigure

$\underline{\text { Page }}$

1 Phase Diagram of Pressure and Temperature Stability Conditions for Methane Hydrates, and Approximate Subsurface Conditions at

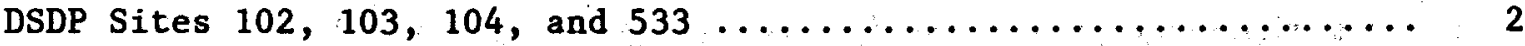

2. Diagrammatical Representation of Effects of Erosion on Gas

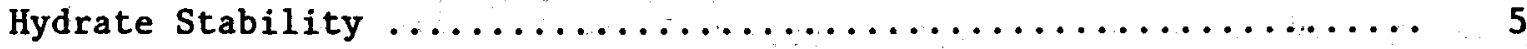

3 Bathymetry of the Blake Outer Ridge Showing the Four DSDP Sites and Line of Cross Section for Figure $6 \ldots \ldots \ldots \ldots \ldots \ldots \ldots \ldots$

4 Seismic Section Across Blake Outer Ridge With the Crestal Region Expanded ............................... 8

5 Areal Extent of BSR on Blake Outer Ridge, Based on LamontDoherty Seismic Reflection Data ...................... g

6 Diagrammatical Cross Section of the Blake Outer Ridge Showing Bathymetric Relationships of Calculated Hydrate Stability.

Zone, BSR, and Chlorinity Minima .....................

7 Chlorinity Logs From the Four DSDP Sites Constructed From

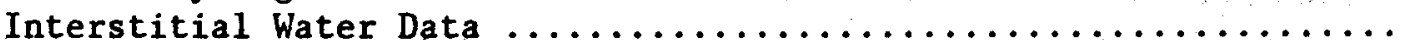

8. Tracing of Bedding Plane Reflectors and BSR .............. 14

\section{LIST OF TABLES}

Table

1 Gas Analysis of Hydrate Sample Recovered at Site $533 \ldots \ldots \ldots \ldots \ldots$

2 Comparison of Blake Outer Ridge With Other Known Hydrate

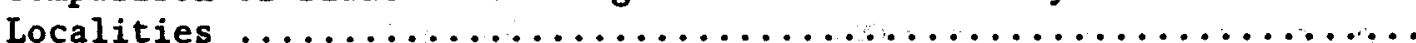




\subsection{INTRODUCTION}

Gas hydrates have recently been noted as an indicator of the geothermal gradient (Yamano and others 1982; MacLeod 1982), as a geologic agent that fractionates oxygen isotopes (Hesse and Harrison 1981), and most significantly, as a possible widespread source of hydrocarbons (Shipley and others 1979). While phase diagrams of methane-water systems (Figure 1) represent an approximation of the natural system and thus provide some basic physical limits on gas hydrate stability, they do not explain why gas hydrates occur in some places where temperature and pressure stability conditions are satisfied and not in others. Furthermore, there have been relatively few attempts to ascertain what, if any, geological factors contribute to hydrate stability, especially in the marine environment. The principal reason for this seems to be a lack of data. Neither shallow nor deep marine environments had been investigated for gas hydrates until a few years ago. It is difficult to confirm the existence of gas hydrates at great depths by coring or drilling, because hydrates tend to at least partially decompose during sampling and transportation to the ocean's surface. Hence, all evidence of gas hydrates may be lost during recovery. In addition, the bottom simulating, reflectors (BSR's) that are frequently associated with gas hydrate occurrences have only recently been recognized in marine seismic records. Their appearance and disappearance are not completely understood. For these reasons, it is difficult to quantify the extent of gas hydrate deposits in the world's oceans.

However, some geological constraints can be developed for marine gas hydrate occurrences by combining available data, conventional geologic reasoning, and knowledge of the phase behavior of gas hydrates. This has been attempted for the Blake Outer Ridge, one of the first marine localities where the existence of gas hydrates was confirmed by recovery of a sample. The general physical and chemical constraints on gas hydrate formation in the marine environment are reviewed in this report. Using data from the DSDP Legs 11 and 76, how these conditions are satisfied at the Blake Outer Ridge is discussed. To the extent it is possible, given the limited amount of data available, generalized descriptions are offered for mechanisms that seem to be important in controlling the stability, distribution, and seismic expression of gas hydrates at the Blake Outer Ridge. While the operation of these mechanisms may be speculative in some cases, it is believed that processes suggested herein will be useful in the further refinement of models of hydrate evolution in oceanic environments.

\subsection{GEOLOGIC FACTORS CONTROLLING GAS HYDRATE FORMATION}

Fundamentally, the formation of gas hydrates in any geologic environment should require only (1) the presence of water, (2) a source of gas, and (3) temperatures and pressures within the gas hydrate stability field (Figure 1). Each of these requirements is discussed.

\subsection{WATER}

Water is abundant in marine sediments, although the amount of water present depends upon porosity. Water forms the cages in which guest molecules become trapped to form hydrate crystals. As with ice, the crystallization of hydrates is inhibited by the presence of dissolved salts in seawater, and many workers use phase diagrams that are based on a water salinity of 3.5 percent. (See Figure 1.) 
TEMPERATURE $\left({ }^{\circ} \mathrm{F}\right)$

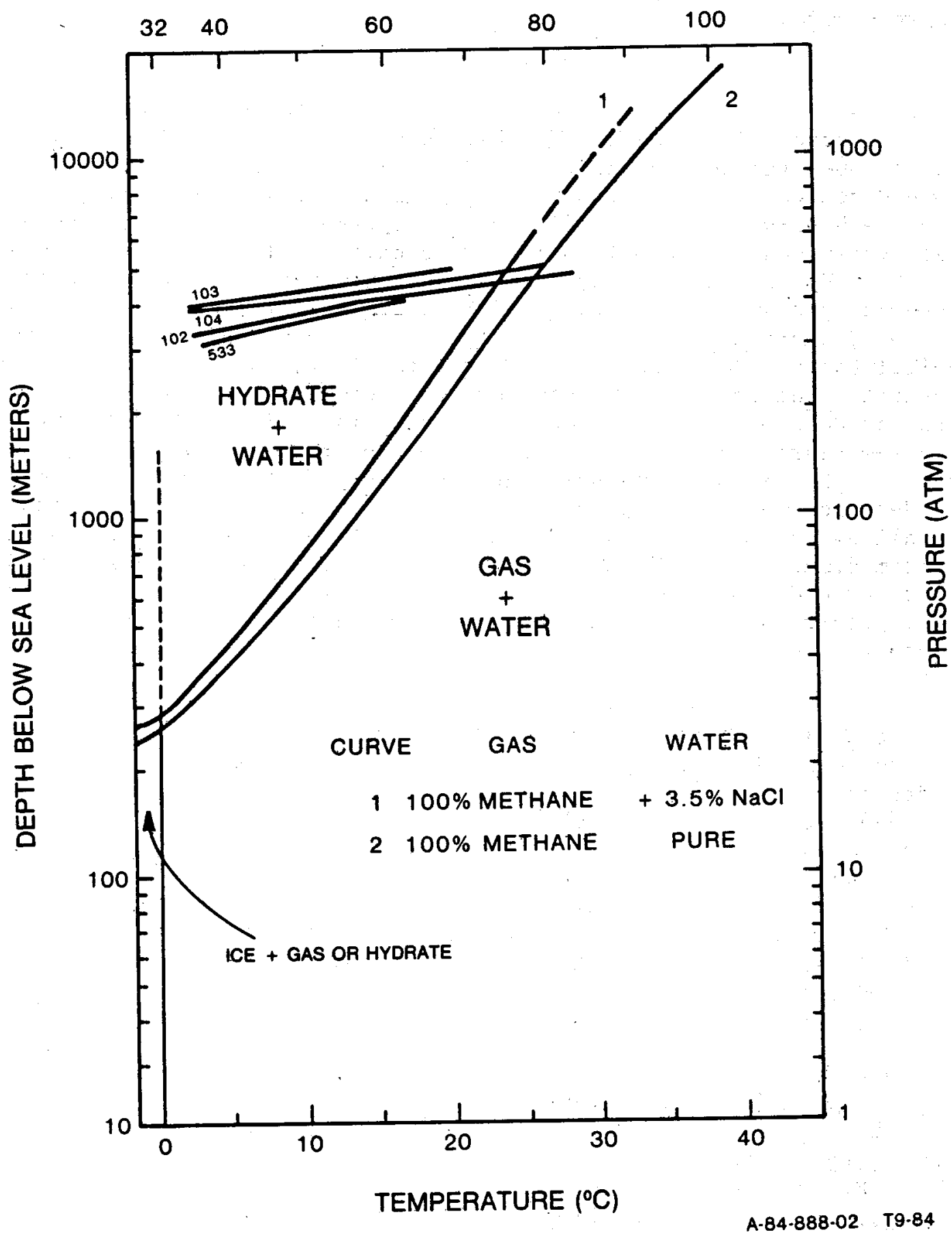

FIGURE 1. PHASE DIAGRAM OF PRESSURE AND TEMPERATURE STABILITY CONDITIONS FOR METHANE HYDRATES, AND APPROXIMATE SUBSURFACE CONDITIONS AT DSDP SITES 102, 103, 104, AND 533

(Modified from Macleod 1982). Nonmethane gases and dissolved salt ions present in the system have opposing effects on hydrate stability and cancel each other (Field and Kvenvolden 1985). Thus, the pure water-pure methane system is a valid approximation for marine environments. 
Dissolved salts are excluded from the crystal structure of hydrates, an effect that may explain observed pore-water salinity fluctuations in hydrate-bearing sections (e.8., Hesse and Harrison 1981; discussed in Section 2.2). Salinity must therefore increase in the vicinity of a growing hydrate, but this increase may be slight even when greater than 50 percent of the available pore space contains gas hydrates (Ridley 1985). Ionic diffusion and fluid migration within marine sediments probably cause any concentrated salt ions to dissipate readily, which normalizes pore-water salinities. This may explain why highly saline pore waters are not commonly associated with recovered gas hydrates. It also suggests that the salting-out effect does not inhibit the growth of gas hydrates.

\subsection{GAS}

Rapid deposition of hemipelagic sediments is a feature of many continental margins. Anoxic conditions are established in seafloor sediments where accumulation is rapid, resulting in the preservation of organic carbon. From this supply of organic carbon, biologic or abiotic processes can produce large volumes of gas, primarily methane. Thermal maturation can produce methane, but Claypool and Kaplan (1974) note that this process is unimportant at temperatures of less than $50^{\circ} \mathrm{C}\left(122^{\circ} \mathrm{F}\right)$. Anaerobic bacteria derive energy from the breakdown of organic matter. They produce methane either by $\mathrm{CO}_{2}$ reduction or by direct acetate fermentation. The mechanisms by which microbial gas production occur are discussed in detail by Rice and Claypool (1981). Anaerobic bacteria are generally held to be the most important producers of gas in the upper 1,000 meters $(3,281 \mathrm{ft}$ ) of the sediment column (Claypool and Kaplan 1974; Claypool and Threlkeld 1983; Kvenvolden and Barnard 1983).

An important question that has not been resolved is the solubility of methane at in situ temperatures and pressures. Rice and Claypool (1981) noted that reliable measurements have not been made in the pressure and temperature region of methane hydrate stability. It is significant that the presence of a gas phase is not necessary to stabilize hydrates (Katz 1972; Hand, Katz, and Verma 1974), which may indicate that methane need not reach bubble-point saturation before hydrates will form.

When the zone of anaerobic methane production is within the boundaries of a hydrate stability zone, gas hydrates should be produced in place, and should be distributed throughout the hydrate stability zone wherever sufficient gas is present. It is possible that gas produced at depth may migrate upward, increasing gas concentration and triggering hydrate formation. If the migrating gas is the only source of guest molecules for hydrate, gas hydrates should form at the base of the hydrate stability zone only. An impermeable hydrate layer, once formed, could prevent further upward migration of gas, and could limit the mobility of underlying free gas, thus constituting a self-sealing gas trap (White 1979; Downey 1984).

\subsection{TEMPERATURE AND PRESSURE CONDITIONS}

The temperature and pressure stability conditions for methane hydrates are shown in the phase diagram in Figure 1 . With increasing depth below the seafloor, temperature and pressure increase. Increased temperature promotes hydrate dissociation, while increased pressure promotes hydrate stability. With a given geothermal gradient, the temperature increase overcomes the pressure increase, $i . e .$, the geothermal gradient intersects the hydrate stability 
boundary. This fact has two important implications. First, there must be a lower boundary to the hydrate stability zone. The depth of the base of the hydrate zone is probably equal to the depth of the bottom simulating reflector (BSR). Some workers have used the depth to the BSR to calculate geothermal gradients, based on this assumption (MacLeod 1982; Yamano and others 1982). Second, hydrate-bearing sediments may eventually be buried to a depth at which they are unstable and where they dissociate.

Rapid sedimentation causes thermal perturbations in the near-surface sediment column, which may affect hydrate stability. Rapid deposition coupled with basin subsidence should depress isotherms. This situation would favor a thick hydrate stability zone in the basin sediments, since the isotherm that controls hydrate stability moves progressively downward, but the temperature at the sedimentwater interface remains constant. Where rapid sedimentation occurs without subsidence, the sediment pile grows away from the heat source at depth and the geothermal gradient decreases. This configuration would also produce a thick hydrate stability zone.

If deposition without subsidence results in the development of a bathymetric high, the surface area of the seafloor per unit cross-sectional area is increased. Heat flow varies as the inverse of the surface area, and so will decrease when surface area is increased. Assuming steady-state conditions in the sediment, heat flow and geothermal gradient are directly proportional when the thermal conductivity of the sediment remains constant. Thus, the decrease in heat flow at the bathymetric high is accompanied by a decrease in the geothermal gradient. The depression of the geothermal gradient causes the base of the hydrate stability zone to occur deeper within the sediments on the bathymetric high than it occurs within smooth seafloor sediments. Therefore, a positive feature on the seafloor is a likely site of a thick hydrate stability zone.

Rapid erosion also causes near-surface thermal perturbations. If there is no change in hydrostatic pressure (e.g., change in sea level), initially the hydrate zone is attenuated, since a portion of the zone in the upper sediment column is removed. As thermal equilibrium is reestablished, the base of the stability zone moves downward and eventually the stability zone returns to its pre-erosion thickness (Figure 2). Thus, although there is no net effect on hydrate zone thickness, erosion does exercise local control on the depth of the hydrate base.

From this general discussion of the basic requirements for gas hydrate formation, two points should be emphasized: (1) although temperature and pressure conditions for hydrate stability are apparently satisfied over much of the world's seafloor, local or regional conditions (e.g., subsidence, rapid deposition, topography) complicate the distribution of gas hydrate; and (2) it is likely that gas hydrates are restricted to continental margins, where rapid deposition of hemipelagic sediment produces anoxic conditions and preserves organic carbon for gas production (Kvenvolden and McMenamin 1980), and where the near-surface geothermal gradient is likely to be low because of rapid deposition and non-subsidence. 


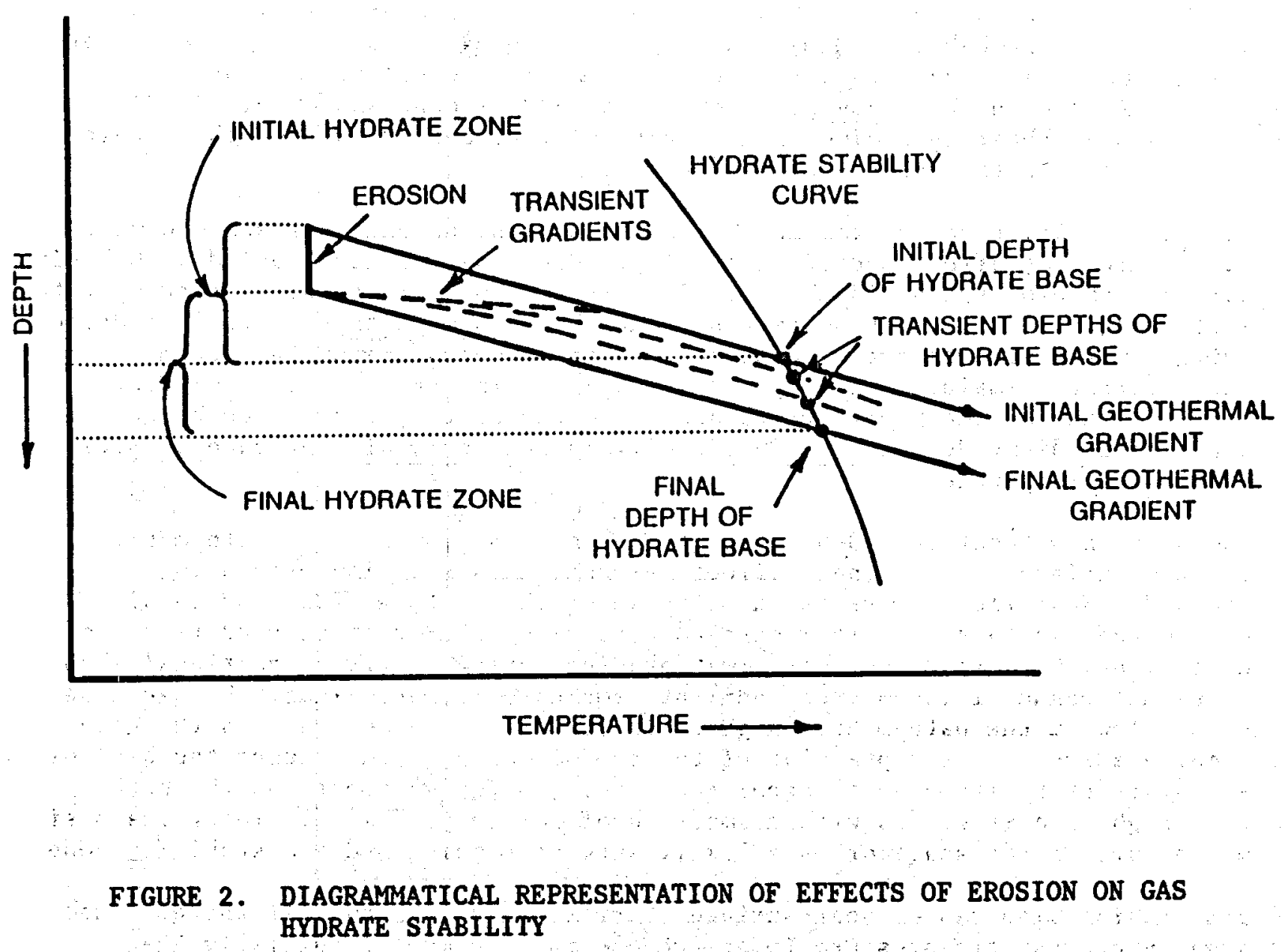

(Modified from Krason and Ridley 1985). Although erosion has no net effect on the thickness of the hydrate stability zone, the hydrate base moves downward relative to its preerosion position.

3.0 GAS HYDRATE OCCURRENCE AT THE BLAKE OUTER RIDGE

\subsection{GEOLOGIC SETTING}

The Blake Outer Ridge, with a maximum relief of $2,900 \mathrm{~m}(9,500 \mathrm{ft})$, is the largest sedimentary ridge in the world's oceans. It extends over $500 \mathrm{~km}$ $(270 \mathrm{nmi})$ southeastward from the Blake Plateau and just south of Cape Hatteras (about $32^{\circ} 30^{\prime} N, 76^{\circ} 30^{\circ} \mathrm{W}$ ) on the passive continental margin of eastern North America. (See Figure 3.)

The Blake Outer Ridge was built on a Cretaceous - to Eocene-age abyssal plain by contour-following currents. Beginning during early Miocené age, the interaction of the north-directed Florida Current with the south-directed Western Boundary Undercurrent stabilized the currents that were flowing clockwise around the growing ridge (Bryan and Markl 1966; Bryan 1970; Mark1, Bryan, and Ewing 1970). $A$ change in current interaction caused a change in depositional style from strata that conformed with the ridge shape, to landward-dipping contourite lenses (Markl and Bryan 1983). 


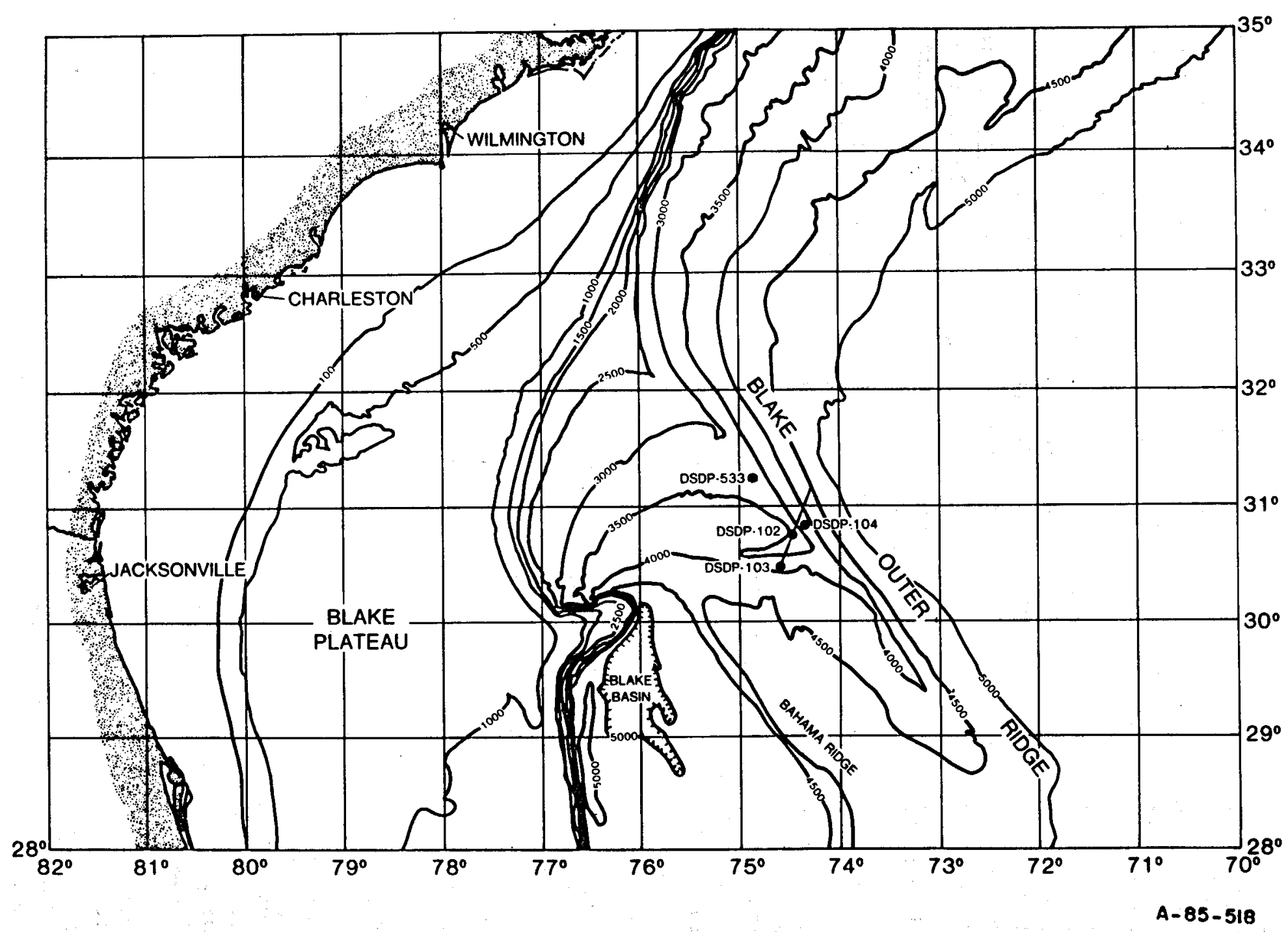

FIGURE 3. BATHYMETRY OF THE BLARE OUTRR RIDGE SHOWTNG THR FOUR DSDP SITES AND LINE OF CROSS SECTION FOR FIGURE 6

(Modified from Flood and Shor 1984) 
The Ridge is constructed principally of grey-green hemipelagic silty muds. Deposition was very rapid ( 80 to $170 \mathrm{~m} / \mathrm{my} ; 260$ to $560 \mathrm{ft} / \mathrm{my}$ ) and led to the preservation of organic carbon (Ewing and Hollister 1972). The percent of carbonate is variable and is irregularly distributed (Lancelot and Ewing 1972; Matsumoto 1983). Although the carbonate was probably initially biogenic, authigenic forms dominate most sections (Matsumoto 1983). Sources of sediment were to the north, transported by the Western Boundary Undercurrent, and to the southeast, transported across the Florida shelf and Blake Plateau by the Florida Current. Terrestrial sources are indicated for organic carbon as well as for clastic sediments (Ewing and Hollister 1972).

Subaqueous erosion has also been important in shaping the Blake Outer Ridge, particularly at the ridge flanks (Jacobi, Vassallo, and Shor 1984). Enhanced deep circulation of the Western Boundary Undercurrent during Pleistocene-age glaciation may have eroded as much as $200 \mathrm{~m}$ (656 ft) from the northeastern flank (Matsumoto 1983).

\subsection{DISCOVERY OF GAS HYDRATES}

Gas hydrates were first suspected to occur at the Blake Outer Ridge in the late $1960^{\prime} \mathrm{s}$ when seismic profiles across the ridge revealed an anomalous reflector (Mark1, Bryan, and Ewing 1970). (See Figure 4.) This reflector " $Y$ " was later discovered to mimic seafloor topography, cut across stratigraphic reflectors, and to increase in subbottom depth with increasing water depth. DSDP Leg 11 investigated the causes of the BSR (Hollister, Ewing, and others 1972). Cores recovered from Sites 102,103 , and 104 contained gas-rich sediments, as evidenced by gas pockets and extruision of sediments from core liners, but no direct evidence of gas hydrates was seen. However, the anomalously high acoustic velocities measured at the three sites led Stoll, Ewing, and Bryan (1971), and Lancelot and Ewing (1972), to propose the existence of gas hydrates at the Blake Outer Ridge.

DSDP Leg 76 confirmed the existence of hydrates when a site was drilled that exhibited a BSR on seismic records. A gas hydrate sample was successfully recovered at Site 533, to the northwest of the Leg 11 sites (Kvenvolden and Barnard 1983).

Several publications have evolved from the DSDP research at the Blake Outer Ridge. Maps showing the distribution of BSR's have been compiled using DSDP and other cruise data by Paull and Dillon (1979); Tucholke, Bryan, and Ewing (1977); and Markl and Bryan (1983). (See Figure 5.) Sheridan, Gradstein, and others (1982) summarized the findings at Site 533. Kvenvolden and Barnard (1983) presented a detailed description of the gas hydrate occurrence at Site 533, and Kvenvolden (1984) compared the geochemistry of gas hydrates at Site 533 the geochemistry of Guatemalan hydrates recovered on DSDP Leg 84 (Site 568). Dillon, Grow, and Paull (1980) discussed the velocity structure of the BSR and the possible development of gas traps beneath impermeable gas hydrate zones in the Blake Outer Ridge region. High resolution seismic reflection data from a northeastward traverse across the ridge were interpreted by Shipley and others (1979), who identified BSR's associated with landward-dipping contourite lenses. 


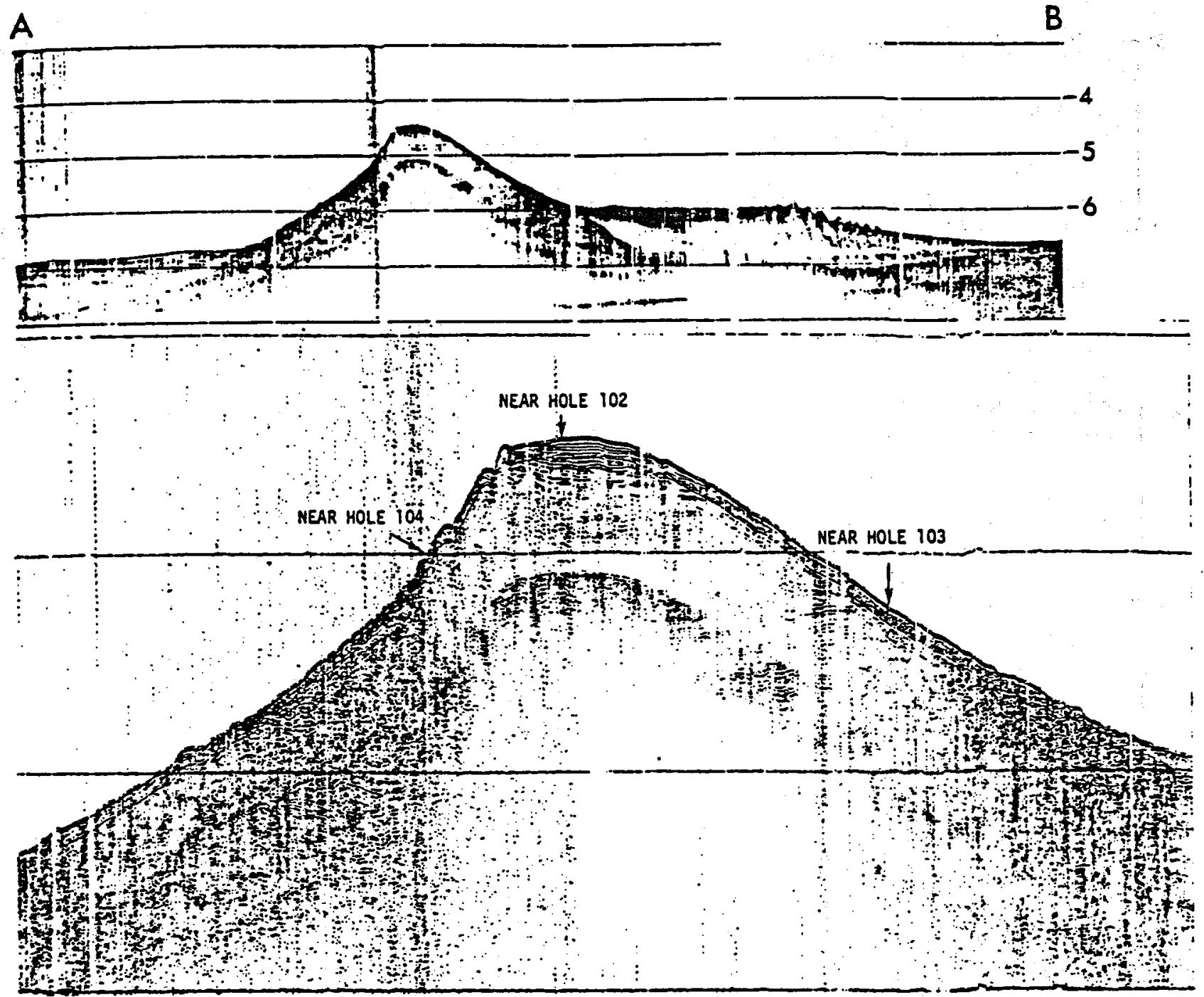

FIGURE 4. SEISMIC SECTION ACROSS BLAKE OUTER RIDGE WITH THE CRESTAL REGION EXPANDED

(From Hollister, Ewing, and others 1972). The BSR cuts across bedding plane reflectors. 


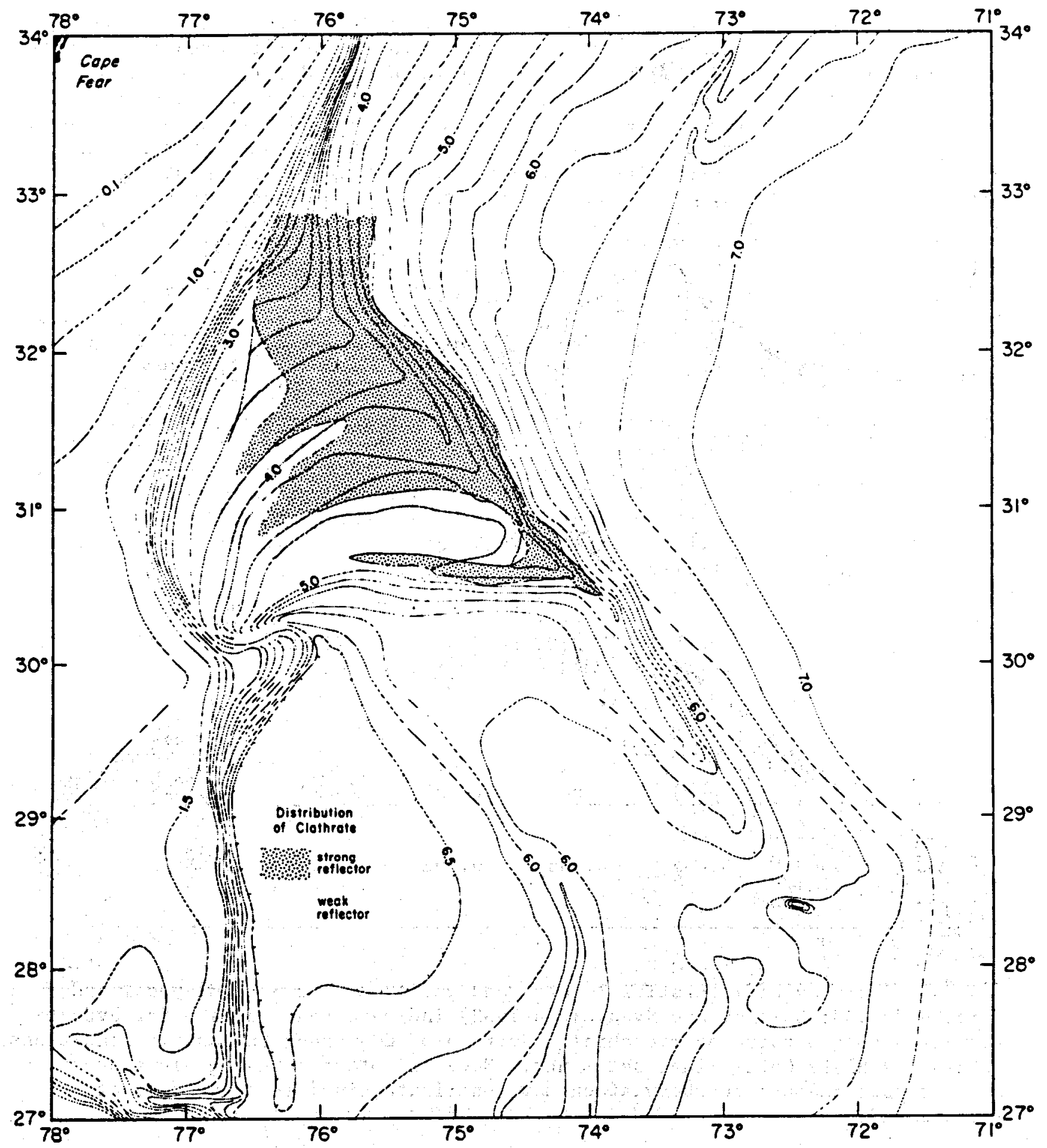

FIGURE 5. AREAL EXTENT OF BSR ON BLAKE OUTER RIDGE, BASED ON IAMONT-DOHERTY SEISMIC REFLECTION DATA

(From Mark1 and Bryan 1983) 


\subsection{GAS GEOCHEMISTRY OF HYDRATES AT SITE 533}

Site 533 was the only DSDP site at the Blake Outer Ridge from which gas hydrates were recovered. The interval containing gas hydrates was recovered from a water depth of $4,600 \mathrm{~m}(15,090 \mathrm{ft})$, at a subbottom depth of $238 \mathrm{~m}$ (780 ft). Small white crystals of gas hydrates were dispersed in $5-$ to $10-\mathrm{cm}$ (2- to 4-in) thick layers of frothy sediment. The crystals occupied about 10 percent of the total pore space of the sediment. Kvenvolden and Barnard (1983) suggest that much of the hydrates must have been finely dispersed throughout the sediment column, so that upon decomposition, there was little evidence of sediment disruption, except in the interval of 152 to $250 \mathrm{~m}$ (500 to $825 \mathrm{ft}$ ) where sediment was disturbed and frothy. Upon recovery, portions of the core were subjected to decomposition experiments. The core was not retrieved at in situ pressure; however, the experiments determined the ratio of gas volume to pore water volume to be $20: 1$, at least four times the solubility of gas in pore water at in situ pressure and temperature conditions. The volumetric measurements can be explained by the presence of gas hydrates in the sample.

Compositional analysis of the gas contained in the recovered hydrate sample (Table 1) reveals methane $\left(C_{1}\right)$ to be the dominant hydrocarbon. Most of the gas hydrates in the sample were, therefore, probably Structure I hydrates. Propane $\left(C_{3}\right)$ and butanes $\left(C_{4}\right)$ may have been present as a few crystals of Structure II hydrates. The $i-C_{5}$ and $n-C_{5}$ molecules must have occurred as either free or dissolved fluids, since these compounds are too large to fit into either Structure I or II hydrate lattices.

TABLE 1. GAS ANALYSIS OF HYDRATE SAMPLE RECOVERED AT SITE 533

(From Kvenvolden and Barnard 1983)

\begin{tabular}{|c|c|c|c|c|c|c|c|}
\hline $\begin{array}{l}\mathrm{C}_{1} \\
(\%)\end{array}$ & $\begin{array}{c}\mathrm{C}_{2} \\
(\mathrm{ppm})\end{array}$ & $\begin{array}{c}\mathrm{C}_{3} \\
(\mathrm{ppm})\end{array}$ & $\begin{array}{l}i-C_{4} \\
\text { (ppm) }\end{array}$ & $\begin{array}{l}n-C_{4} \\
(\mathrm{ppm})\end{array}$ & $\begin{array}{l}i-C_{5} \\
(\mathrm{ppm})\end{array}$ & $\begin{array}{l}\mathrm{n}-\mathrm{C}_{5} \\
(\mathrm{ppm})\end{array}$ & $\begin{array}{l}\mathrm{CO}_{2} \\
(\%) \\
\end{array}$ \\
\hline 98.596 & 3.369 & 0.055 & 0.055 & 0.002 & 0.004 & 0.004 & 1.369 \\
\hline
\end{tabular}

Isotopic analyses of interstitial water and gas from Site 533 (Claypool and Threlkeld 1983; Galimov and Kvenvolden 1983) indicate that methane for hydrate formation is generated by microbial reduction of $\mathrm{CO}_{2}$ under the anoxic conditions within the Blake Outer Ridge sediments. However, other methanogenic process such as spontaneous decarboxylation may contribute significant volumes of methane and cannot be excluded on the basis of the isotopic analyses.

\subsection{CONTROLS ON HYDRATE OCCURRENCE AT THE BLAKE OUTER RIDGE}

The DSDP surveys on Legs 11 and 76 provide much information on the geological framework of gas hydrate occurrences at the Blake Outer Ridge. Figure 6 summarizes the physical and chemical data from the four drill sites in a diagrammatical cross section of the ridge. Assumed values listed in Figure 6 were 
SOUTH

NORTH

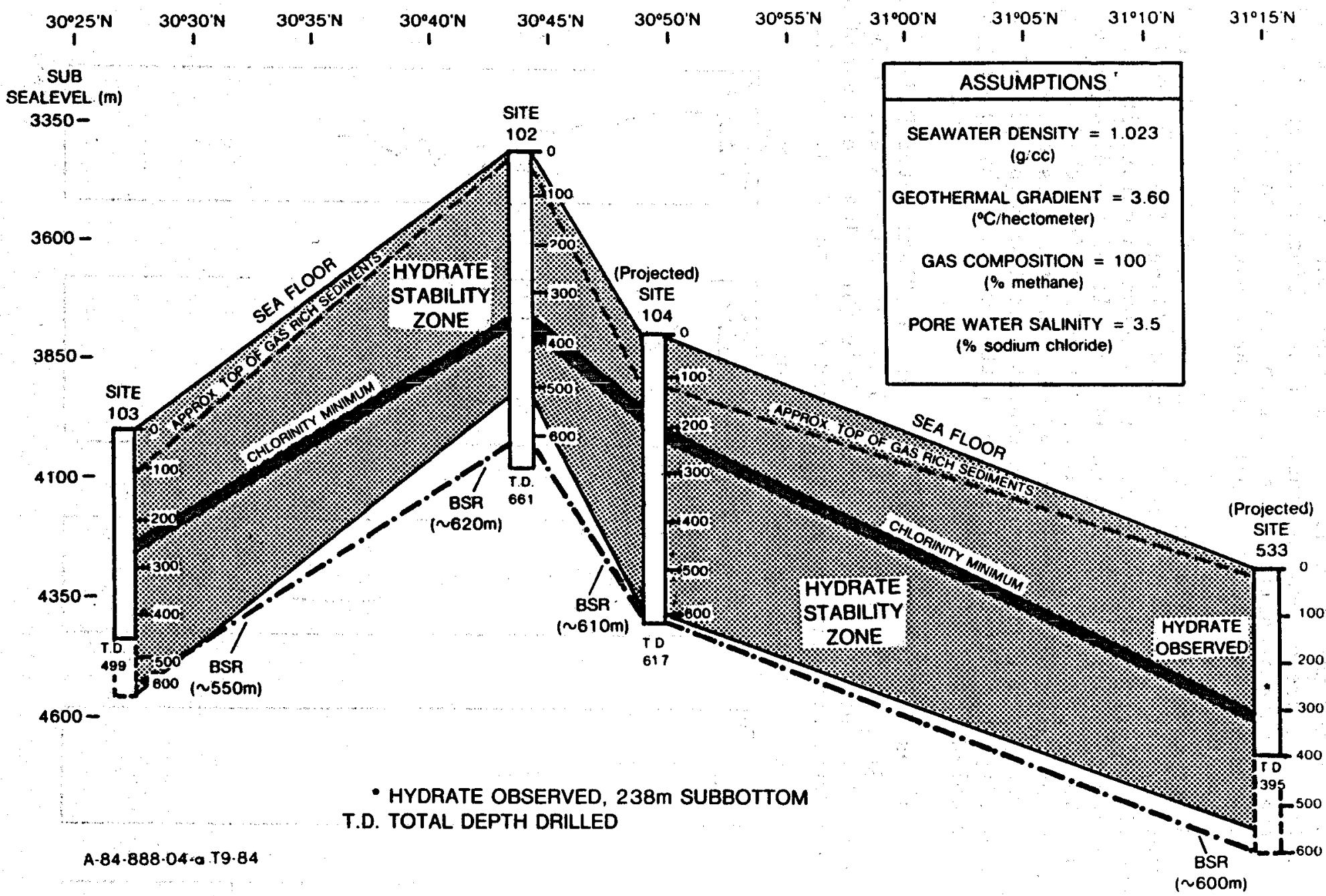

FIGURE 6. DIAGRAMMATICAL CROSS SECTION OF THE BLAKE OUTER RIDGE SHOWING BATHYMETRIC RELATIONSHIPS OF CALCULATED HYDRATE STABILITY ZONE, BSR, AND CHLORINITY MINIMA

The actual gas hydrate zone probably extends from the top of gas-rich sediments to the BSR, although hydrate could be stable at the seafloor. 
adopted from the DSDP site reports. Downhole pressures and temperatures were calculated using these assumed values, sediment wet bulk density data from the site reports, and bottom-water temperature data (Fuglister 1960; Amos, Gordon, and Schneider 1971). Figure 6 does not show an exact coincidence of the BSR and the base of the hydrate stability zone as might be expected, because a single geothermal gradient was used to construct the cross section.

Gas hydrate formation excludes salt ions from the crystal lattice. During the hydrate dissociation that is caused by coring and drilling, fresh water is released. Downhole chloride ion concentration, as shown on chlorinity profiles from squeezed sediment samples, may decrease as a result of the dilution of normal seawater. Thus, pore water freshening, determined from chlorinity logs, may be a reliable indicator of the presence of gas hydrates (Hesse and Harrison 1981). Kvenvolden (1984) even speculates that the magnitude of the decrease in chlorinity is a direct indication of the amount of hydrates present in the interval sampled.

The chlorinity profiles for the four DSDP sites at the Blake Outer Ridge are shown in Figure 7. At only two sites (102 and 533) were pore waters analyzed for the entire drilled interval; only one drill hole (Site 104) terminated near the base of the hydrate stability zone (corresponding to the BSR). Still, there

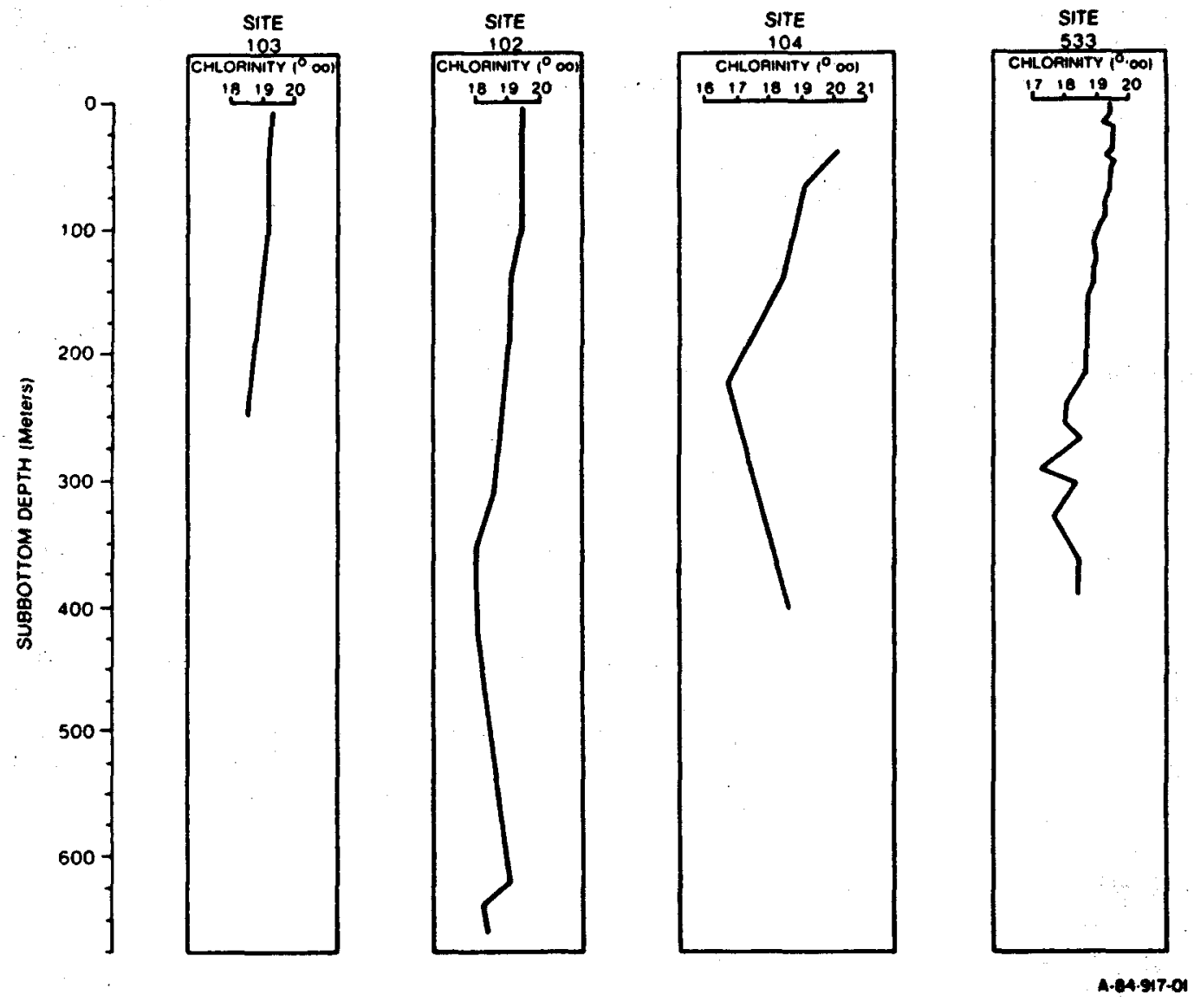

FIGURE 7. CHLORINITY LOGS FROM THE FOUR DSDP SITES CONSTRUCTED FROM INTERSTITIAL WATER DATA

(Water data from Sayles, Monheim, and Waterman 1972; and Jenden and Gieskes 1983) 
is a discernible downhole freshening trend, which may be attributable to the presence of gas hydrates. Site $533^{\prime}$ 's profile shows three well-defined deflections in the interval where gas hydrates were observed. These deflections may be related to the diffusion of chloride ions above and below a hydrate rich layer, as suggested by Jenden and Gieskes (1983). Downhole chloride ion concentrations appear to reach a minimum within the zone of hydrate stability. The approximate downhole location of the chlorinity minimum for each hole (using the apparent minima for sites 103 and 104) is plotted in Figure 6. The correlation of these minima is for illustration purposes, and is not based on actual data.

According to the phase diagram, gas hydrates could be stable at the sedimentwater interface. However, the first indication of gas within the sediments (e.g., gas voids, frothy textures) occurs at subbottom depths between 25 and $125 \mathrm{~m}$ ( 80 to $410 \mathrm{ft}$ ). It is likely that gas hydrates do not occur at depths shallower than these because there is probably insufficient gas within the sediments. However, since no accurate measurements were made of the gas volume at in situ pressures and temperatures, this is only a first approximation of the location of the top of the hydrate zone.

Upward migration of gas from sources below the base of the hydrate stability zone may be controlled by the geometry of the bedding planes with respect to the hydrate base. In particular, seismic records from the Blake Outer Ridge show that reflectors beneath the strong BSR in the crestal region dip toward each other, opposite the dip of the BSR (Tucholke, Bryan, and Ewing 1977). (See Figure 8.) This configuration would cause upward-migrating gas to reach the lower stability boundary and to form hydrates, creating an impermeable layer. Gas trapped beneath this horizon may be responsible for the acoustic impedance contrast that is associated with the BSR (Dillon, Grow, and Paull 1980).

An implicit requirement of this model is the ability of gas to migrate upward and along bedding planes in the shallow-dipping clay sediments of the ridge. If gas migration below the BSR is accepted, it is also important to consider the possibility of, and controls on, gas migration above the BSR.

Examination of the seismic cross section of the Blake Outer Ridge reveals that although the ridge is an antiformal feature, it does not possess the bedding plane geometry of an anticline. That is, beds on opposite flanks of the ridge do not necessarily dip away from each other, creating a trap at the crest. In the near-surface sediments, dips of beds change across the ridge (Figure 8 ). Those at the ridge crest are nearly horizontal. If gas generated in the sediments can migrate along the bedding planes, then the bedding plane geometry above the BSR indicates that the gas above the BSR escapes from the stability zone and perhaps from the system, thus preventing hydrate formation.

Yet gas hydrates are above the level of the BSR, as demonstrated at Site 533. This suggests that gas concentration above the BSR may be controlled by some property of the sediment, rather than by bedding plane geometry. Low sediment permeability may permit gas to accumulate in sediments faster than it can escape and the onset of hydrate formation would further decrease local permeability. Gas hydrates may form in the stability zone from gas produced in place, so migration may not be necessary. If hydrate formation in the upper stability zone is not strictly dependent on gas mobility, it is difficult to 


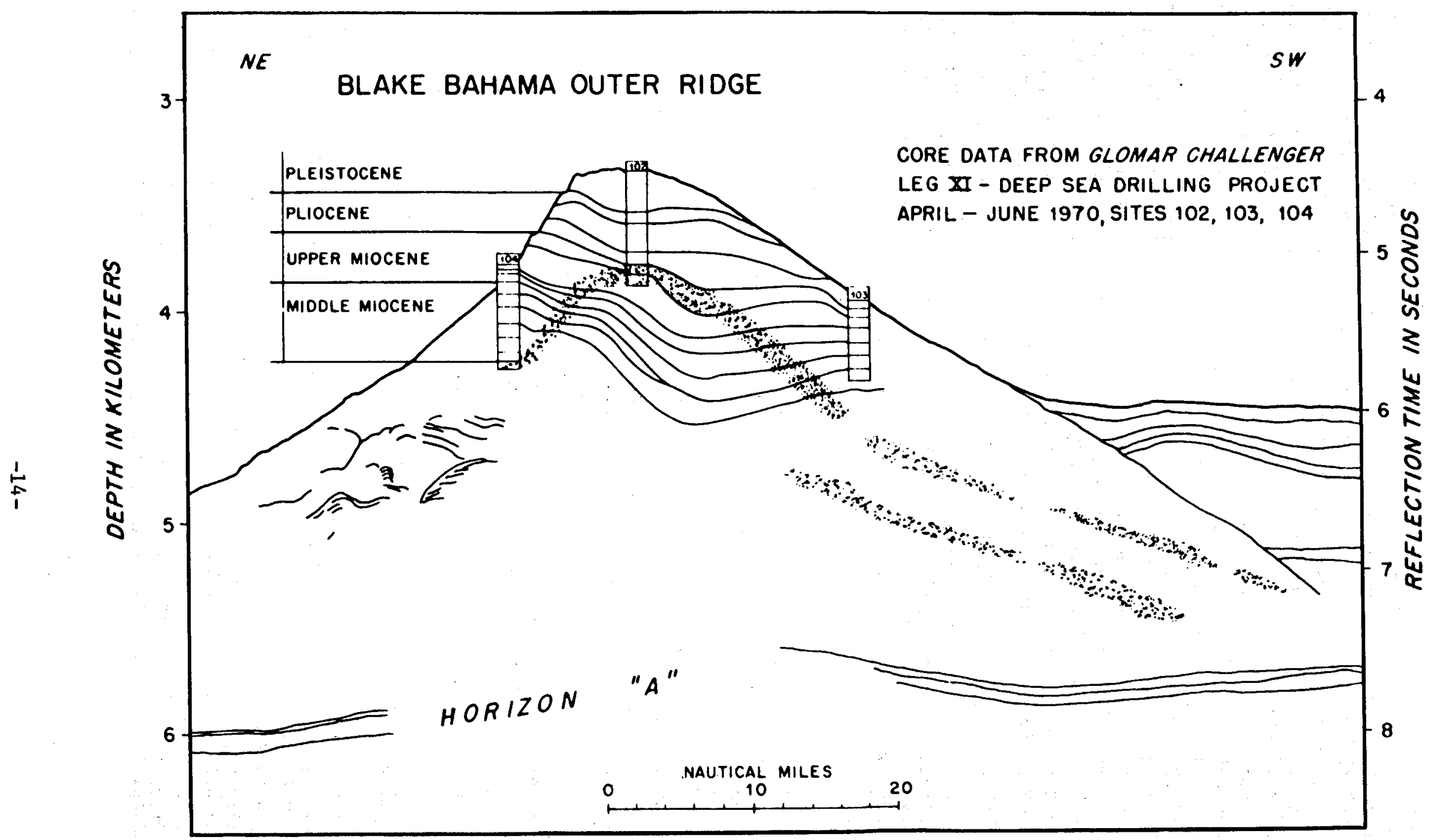

FIGURE 8. TRACING OF BEDDING PLANE REFLECTORS AND BSR

(From Hollister, Ewing, and others 1972) 
predict where gases will be sufficiently concentrated to form hydrates at the Ridge. This is because the rates of gas generation and migration within the low permeability sediments have not been quantified. However, rates of gas generation have been estimated (Claypool and Threlkeld 1983).

Another aspect of the depositional setting of the Blake Outer Ridge that may be important is the thermal regime that has been created by the convex shape of the Ridge. Because of its shape, the ridge has a large surface area compared to its horizontal area, causing decreased heat flow and a decreased geothermal gradient relative to the adjacent smooth seafloor (Macleod 1982). This creates cooler temperatures at a given depth beneath the ridge surface than those encountered at the same depth beneath the adjacent smooth seafloor. Consequently, the isotherm that controls the base of the hydrate stability zone should exist deeper beneath the ridge surface than beneath smooth seafloor. This allows for a greater volume of gas-bearing sediments to occupy the hydrate stability zone within the ridge and to form gas hydrates.

It is generally accepted that the BSR represents the base of the hydrate stability zone, and it has been suggested that free gas beneath the hydrates is responsible for the acoustic impedance contrast causing the BSR (Bryan 1974; Tucholke, Bryan, and Ewing 1977). While the BSR may become undetectable where it becomes conformable with bedding plane reflectors, this does not explain the weakening of the BSR at the Blake Outer Ridge near Site 103 (Figure 8). It has been noted by some workers that rapid erosion has occurred at the ridge. Matsumoto (1983) estimated that 110 to $200 \mathrm{~m}$ (360 to $650 \mathrm{ft}$ ) of sediment were eroded from the ridge flanks during Pleistocene-age glaciation, based on carbonate mineral zonations. Echo character mapping by Jacobi, Vassallo, and Shor (1984) showed signs of rapid erosion near Site 103, at the mapped limit of the BSR according to Markl and Bryan (1983). An explanation for the disappearance of BSR's, advanced by Paull and Dillon (1979), may apply at the ridge: erosion causes local, but transient, increases in heat flow and geothermal gradient as once-buried sediments come in contact with seawater. The isotherm that controls the base of the hydrate stability zone migrates downward as the sediment column cools. Free gas that once existed below the hydrate base becomes incorporated into gas hydrates. Thus, the acoustic impedance contrast that existed between the hydrate-cemented sediments above and the free gas below is lost, and the BSR vanishes even though gas hydrates may be present. The loss of the BSR may be temporary, since free gas may eventually accumulate beneath the new hydrate base in sufficient concentrations to create another acoustic velocity contrast.

\subsection{OTHER GAS HYDRATE OCCURRENCES}

Gas hydrates have been recovered from two marine settings that are somewhat different from the Blake Outer Ridge. The landward side of the Middle America's trench off southern Mexico and western Guatemala yielded hydrates at Site 492 (Watkins, Moore, and others 1981), Sites 497 and 498 (Aubouin, von Huene, and others 1982), and Sites 568 and 570 (von Huene, Aubouin, and others in press). Numerous gas hydrate samples have been recovered in the slope sediments of the northwestern and north-central Gulf of Mexico (Brooks, Cox, and Kennicutt 1984; Leg 96 Scientific Party 1984). The major similarities and differences among the Blake Outer Ridge and these sites are summarized in Table 2. 
TABIE 2. COMPARISON OF BLAKE OUTER RIDGE WITH OTHER KNOWN HYDRATE LOCALITIES

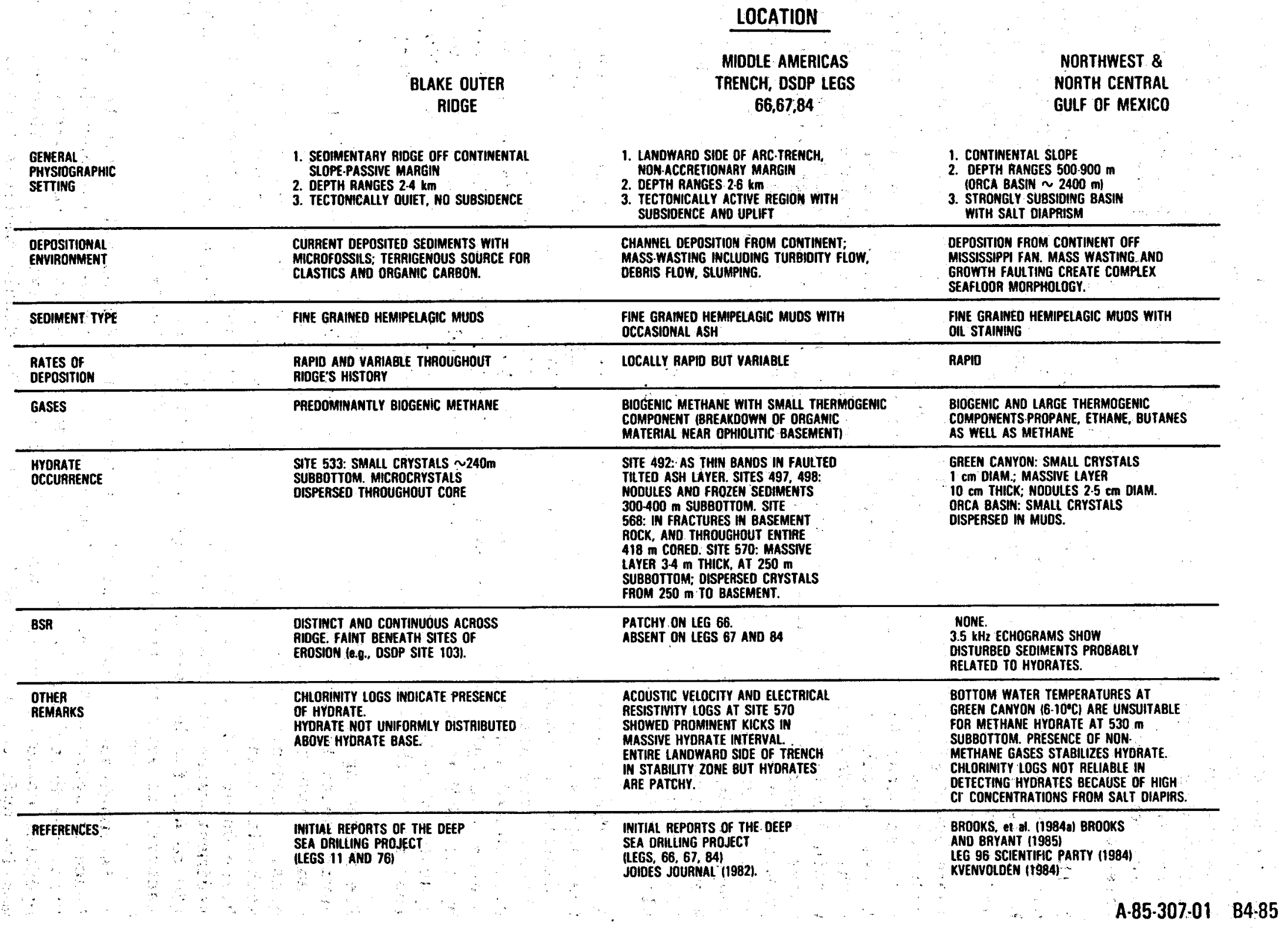


All three sites are characterized by rapid deposition of hemipelagic sediment, which preserves organic carbon for eventual gas production. The Middle America's trench slope is similar to the Blake Outer Ridge in water depths and bottom water temperatures. The northern Gulf of Mexico is tectonically similar to the Blake Outer Ridge as a passive continental margin depocenter. However, in most other geologic aspects, the three localities are different and represent three distinct environments for gas hydrate occurrence.

In the north and northwestern Gulf of Mexico, bottom water temperatures are warmer and depths are shallower than at the Blake Outer Ridge. Sediment instability is widespread. Gas hydrates of both thermogenic and biogenic origin have been recovered in the fine-grained sediments of the Green Canyon area.

Thermogenic gas hydrates that have been recovered contain a large portion of hydrocarbons other than methane, e.g., ethane, propane, and butane. These hydrates occur in association with oil-stained sediments. As indicated by Brooks and others (1984), these hydrocarbons have migrated upward from deep within the sedimentary column. These mixed-hydrocarbon hydrates can occur within $2 \mathrm{~m}$ (about $7 \mathrm{ft}$ ) of the sediment-water interface, where warm bottom water temperatures and depths of 500 to $600 \mathrm{~m}(1,650$ to $1,980 \mathrm{ft})$ would not permit pure methane hydrates to be stable. Biogenic gas hydrates have been recovered and consist primarily of methane. These hydrates are restricted to deeper water; the Orca Basin (about 2,400 m; about 8,000 ft) is the deepest known biogenic hydrate locality in the Gulf. Unlike the Blake Outer Ridge, no BSR's have been observed in connection with gas hydrates in the continental slope region of the northern Gulf of Mexico.

At the Middle America's trench, evidence of tectonic uplift and subsidence since the slope's formation have been reported (JOIDES Journal 1982). Near-surface sediments are commonly subjected to mass wasting, and are thus less stable than those at the Blake Outer Ridge. The BSR is absent, and hydrate is irregularly distributed and variable in character. Unlike the Blake Outer Ridge, at least one massive hydrate zone, approximately $3 \mathrm{~m}(9.8 \mathrm{ft})$ thick has been discovered by the DSDP at Site 570 (von Huene, Aubouin, and others. In press). Gas hydrates were encountered in low concentrations throughout the lower $200 \mathrm{~m}$ $(660 \mathrm{ft})$ of the $418 \mathrm{~m}(1380 \mathrm{ft})$ drilled at DSDP Site 568 (JOIDES Journal 1982).

The preceding paragraphs serve to illustrate the variability of possible environments for hydrate formation. The only characteristic the three sites seem to have in common is rapid hemipelagic sedimentation on continental margins. Abundance of gas appears to be the limiting factor where other hydrate stability conditions are satisfied. This is most clearly demonstrated at the Blake Outer Ridge, where the hydrate stability zone extends from the BSR to the sediment-water interface, but hydrates are absent in the upper 25 to $125 \mathrm{~m}$ ( 80 to $410 \mathrm{ft}$ ) because of low gas concentrations. It is not clear what other factors, if any, are necessary for gas hydrate formation.

It is important to note that the presence of a BSR usually indicates the existence of hydrates (diagenetic boundaries may produce similar anomalous reflectors; see Hein, and others 1981), but the reverse is not necessarily true; hydrates do not always produce strong BSR's. For example, the thickest zone of massive hydrates discovered to date (Site 570, Middle Americas trench) apparently has no associated BSR. Thus, worldwide marine hydrate occurrence may be even more widespread than the distribution of BSR's indicates. (See Shipley and others 1979 for a summary of BSR occurrences.) 


\subsection{SUMMARY}

The occurrence of gas hydrates at the Blake Outer Ridge is not as straightforward as it first appears from examination of the phase relationships of gas and-water. In general, hydrate occurrence is governed by gas availability, low temperatures, and high pressures. But each of these controls is dependent on subtle and complex geological factors, such as seafloor processes, gas compositions, sediment permeability, and, particularly at the Blake Outer Ridge, topography. The description of gas hydrate occurrences in the northern Gulf of Mexico and Middle America's trench reinforces the notion of the complex relationships between geology and hydrate stability.

Some general conclusions on the hydrate occurrence at the Blake Outer Ridge have arisen from this study, however. Data from the four DSDP drill sites suggest that the hydrate zone extends from 25 to $125 \mathrm{~m}(80$ to $410 \mathrm{ft}$ ) below the sediment-water interface to about $600 \mathrm{~m}$ (1970 ft) subbottom depth. On the basis of data from the four holes, most of the gas hydrates within the hydrate zone at the Blake Outer Ridge probably occur as small crystals in the pore spaces of the hemipelagic muds, rather than as widespread massive horizons. The loss of the BSR's on the ridge flanks, particularly in the vicinity of Site 103, is probably related to local erosion and cooling, and does not necessarily indicate a depletion of hydrates. Deep drilling elsewhere on the ridge would probably produce gas hydrates or evidence thereof.

\subsection{REFERENCES}

Amos, A.F., A.L. Gordon, and E.D. Schneider. 1971. Water Masses and Circulation Patterns in the Region of the Blake-Bahama Outer Ridge. In Deep Sea Research. Vol. 18, p. 145-165.

Aubouin, J., R. von Huene, and others'. 1982. Initial Reports of the Deep Sea Drilling Project. Vol. 67. Washington, DC. U.S. Government Printing Office.

Brooks, J.M., and W.R. Bryant. 1985. Geological and Chemical Implications of Gas Hydrates in the Gulf of Mexico, Quarterly Technical Progress Report, January-March. Texas A\&M University Department of Oceanography, Grant Number $8 \overline{4 M C 21088 . ~(I n ~ p r e s s) . ~}$

Brooks, J.M., H.B. Cox, and M.C. Kennicutt II. 1984. Gas Hydrate Discoveries in the Gulf of Mexico. EOS. Vol. 65, p. 961.

Brooks, J.M., M.C. Kennicutt II, R.R. Fay, and T.J. McDonald. 1984. Thermogenic Gas Hydrates in the Gulf of Mexico. Science. Vol. 225, p. 409-411.

Bryan, G.M. 1970. Hydrodynamic Model of the Blake Outer Ridge. Journal of Geophysical Research. Vol. 75, p. 4530-4537.

Bryan, G.M. 1974. In Situ Indications of Gas Hydrates. In Natural Gases in

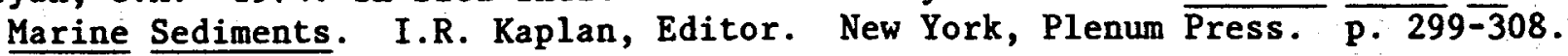

Bryan, G.M., and R.G. Markl. 1966. Microtopography of the Blake-Bahama Region. Lamont-Doherty Geological Observatory Technical Report 8. CU-8-66-Nobsr 85077. 
Claypool, G.E., and I.R. Kaplan. 1974. The Origin and Distribution of Methane in Marine Sediments. In Natural Gases in Marine Sediments. I.R. Kaplan, Editor, New York, Plenum Press. p. 99-139.

Claypool, G.E., and C.N. Threlkeld. 1983. Anoxic Diagenesis and Methane Generation in Sediments of the Blake Outer Ridge, Deep Sea Drilling Project Site 533, Leg 76. In Initial Reports of the Deep Sea Drilling Project. Vol. 72 , p. 391-402.

Dillon, W.P., J.A. Grow, and C.K. Paull. 1980. Unconventional Gas Hydrate Seals May Trap Gas off Southeast U.S. Oil and Gas Journal. Vol. 78, p. 124-130.

Downey, M.W. 1984. Evaluating Seals for Hydrocarbon Accumulation. American Association of Petroleum Geologists Bulletin. Vol. 68, p. 1752-1763.

Ewing, J.I, and C.D. Hollister. 1972. Regional Aspects of Deep Sea Drilling in the Western North Atlantic. In Initial Reports of the Deep Sea Drilling Project. Vol. 11, p. 951-973.

Field, M.E., and K.A. Kvenvolden. 1985. Gas Hydrates Beneath the Continental Slope off Northern California. American Association of Petroleum Geologists Bulletin. Vol. 62, p. 255.

Flood, R.D., and A.N. Shor. 1984. Bathymetry (map), Eastern North American Margin and Adjacent Ocean Floor, $28^{\circ}$ to $36^{\circ} \mathrm{N}$ and $70^{\circ}$ to $82^{\circ} \mathrm{W}$. Ocean Margin Drilling Program Regional Atlas Series, Atlas 5. G.M. Bryan and J.R. Heirtzler, Editors. Margin Science International, Woods Hole, Massachusetts.

Fuglister, F.C. 1960. Atlantic Ocean Atlas of Temperature and Salinity Profiles and Data From the International Geophysical Year of 1957-58. Woods Hole Oceanographic Institution Atlas Series. Vo1. 1, 209 p.

Galimov, E.M., and K.A. Kvenvolden. 1983. Concentrations and Carbon Isotopic Compositions of $\mathrm{CH}_{4}$ and $\mathrm{CO}_{2}$ in Gas From Sediments of the Blake Outer Ridge, Deep Sea Drilling Project Leg 76. In Initial Reports of the Deep Sea Drilling Project. Vol. 76, p. 403-407.

Hand, J.H., D.L. Katz, and V.K. Verma, 1974. Review of Gas Hydrates With Implications for Ocean Sediments. In Natural Gases in Marine Sediments. I.R. Kaplan, Editor. New York, Plenum Press, P.179-194.

Hein, J.R., D.W. Scholl, J.A. Barron, M.G. Jones, and S. Miller 1978. Diagenes is of Late Cenozoic Diatomaceous Deposits and Formation of the Bottom Simulating Reflector in the Southern Bering Sea. Sedimentology. Vol. 25, p. $155-181$.

Hesse, R., and W.E. Harrison. 1981. Gas Hydrates (Clathrates) Causing PoreWater Freshening and Oxygen Isotope Fractionation in Deep-Water Sedimeptary Sections of Continental Margins. Earth and Planetary Science Letters. Vol. 55, p. $453-462$.

Hollister, C.D, J.I. Ewing, and others, 1972. Site 101: Blake-Bahama Outer Ridge (Southern End), and Sites 102, 103, 104: Blake-Bahama Outer Ridge (Northern End). In Initial Reports of the Deep Sea Drilling Project. Vol. 11, p. 105-218. 
Jacobi, R.D., K.L. Vassallo, and A.N. Shor. 1984. Echo Character, Microphysiography, and Geologic Hazards (map), Eastern North American Margin and Adjacent Ocean Floor, $28^{\circ}$ to $36^{\circ} \mathrm{N}$ and $70^{\circ}$ to $82^{\circ} \mathrm{W}$. Ocean Margin Drilling Program Regional Atlas Series, Atlas 5. G.M. Bryan and J.R. Heirtzler, Editors. Marine Science International, Woods Hole, Massachusetts.

Jenden, P.D., and J.M. Gieskes. 1983. Chemical and Isotopic Composition of Interstitial Water From Deep Sea Drilling Project Sites 533 and 534... In Initial Reports of the Deep Sea Drilling Project. Vol. 76, p. 453-462.

JOIDES Journal. 1982. Vol. VIII. Leg 84 Cruise Summary, June 1982. p. 9-14.

Katz, D.L. 1972. Depths to Which Frozen Gas Fields May be Expected -- Footnotes. Journal of Petroleum Technology. Vol. 24, p. 557.

Krason, J., and W.I. Ridley. 1985. Evaluation of the Geological Relationships to Gas Hydrate Formation and Stability: I -- Blake Outer Ridge, Gas Hydrate

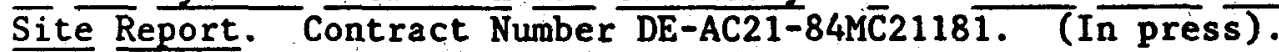

Kvenvolden, K.A. 1984. Comparison of Marine Gas Hydrates in Continental Margin Sediments. Paper presented at Annual Meeting of AIChE, Atlanta, Georgia, March 1984.

Kvenvolden, K.A., and L.A. Barnard. 1983. Gas Hydrates of the Blake Outer Ridge, Site 533, Deep Sea Drilling Project Leg 76. In Initial Reports of the Deep Sea Drilling Project. Vol. 76, p. 353-365.

Kvenvolden, K.A., and M.A. McMenamin. 1980. Hydrates of Natural Gas: A Review of Their Geologic Occurrence. U.S. Geological Survey, Circular $\overline{825} . \overline{1} \frac{\mathrm{p}}{\mathrm{p}}$

Lancelot, Y., and J.I. Ewing. 1972. Correlation of Natural Gas Zonation and Carbonate Diagenesis in Tertiary Sediments From the North-West. Atlantic. In Initial Reports of the Deep Sea Drilling Project. Vol. 11, p. 191-799.

Leg 96 Scientific Party. 1984. Challenger Drills Mississippi Fan. Geotimes. July 1984 , p. 15-18.

Markl, R.G., and G.M. Bryan. 1983. Stratigraphic Evolution of Blake Outer Ridge. American Association of Petroleum Geologists Bulletin. Vol. 67, p. 666-683.

Markl, R.G., G.M. Bryan, and J.I. Ewing. 1970. Structure of the Blake-Bahama Outer Ridge. Journal of Geophysical Research. Vol. 75, p. 4539-4555.

MacLeod, M.K. 1982. Gas Hydrates in Ocean Bottom Sediments. American Association of Petroleum Geologists Bulletin. Vol. 66, p. 264

Matsumoto, R. 1983. Mineralogy and Geochemistry of Carbonate Diagenesis of the Pliocene and Pleistocene Hemipelagic Mud on the Blake Outer Ridge, Site 533, Leg 76. In Initial Reports of the Deep Sea Drilling Project. Vol. 76, p. $41 \mathrm{i}-427$.

Paull, C.K., and W.P. Dillon. 1979. Appearance and Distribution of the Gas Hydrate Reflection in the Blake Ridge Region, offshore Southeastern United

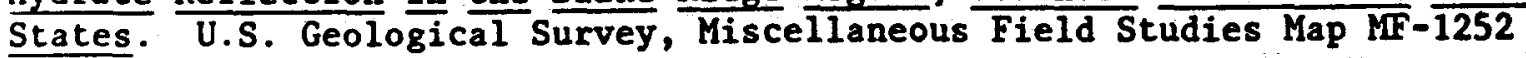
(1 sheet). 
Rice, D.D., and G.E. Claypool. 1981. Generation, Accumulation, and Resource Potential of Biogenic Gas. American Association of Petroleum Geologists Bulletin. Vol. 65, p. 5-25.

Ridley, W.I. 1985. U.S. Geological Survey. Personal Communication with K.L. Dominic.

Sayles, F.L., F.T. Manheim, and I.S, Waterman. 1972. Interstitial Water Studies on Small Core Samples, Leg 76. In Initial Reports of the Deep Sea Drilling Project. Vol. 11, p. 997-1008.

Sheridan, R.E., F.M. Gradstein, and others. 1982. Early History of the Atlantic Ocean and Gas Hydrates on the Blake Outer Ridge; Results of the Deep Sea Drilling Project, Leg 76. Geological Society of America Bulletin. Vol. 93, p. 876-885.

Shipley, T.H., M.H. Houston, R.T. Buffler; F.J. Schaub, K.J. McMillen, J.W. Ladd, and J.L. Worzel. 1979. Seismic Evidence for Widespread Possible Gas Hydrate Horizons on Continental Slopes and Rises. American Association of Petroleum Geologists Bulletin. Vol. 63, p. 2204-2213.

Stoll, R.D., J.I. Ewing, and G.M. Bryan. 1971. Anomalous Wave Velocities in Sediments Containing Gas Hydrates. Journal of Geophysical Research. Vol. 76, p. 2090-2094.

Tucholke, B.E., G.M. Bryan, and J.I. Ewing. 1977. Gas-Hydrate Horizons Detected in Seismic-Profiler Data From the Western North Atlantic. American Association of Petroleum Geologists Bulletin. Vol. 61, p. 698-707.

von Huene, R., J. Aubouin, and others. In press. Initial Reports of the Deep Sea Drilling Project. Vol. 84. Washington, DC. U.S. Government Printing Office.

Watkins, J..S., J.C. Moore, and others. 1981. Initial Reports of the Deep Sea Drilling Project. Vol. 66. Washington, DC. U.S. Government Printing Office.

White, R.S. 1979. Gas Hydrate Layers Trapping Free Gas in the Gulf of Oman. Earth and Planetary Science Letters. Vo1. 42, p. 114-120.

Yamano, M., S. Uyeda, Y. Aoki, and T.H. Shipley. 1982. Estimates of Heat Flow, Derived From Gas Hydrates. Geology. Vol. 10, p. 339-343.

廿U.S. GOVERNMENT PRINTING OFFICE: 1986-631-076/20148 



